\title{
SNAI1 Gene
}

National Cancer Institute

\section{Source}

National Cancer Institute. SNA/1 Gene. NCI Thesaurus. Code C91260.

This gene plays a role in the regulation of both transcription and embryonic development. 